\title{
Characteristics of Thai Pigmented Rice Milk Kefirs with Potential as Antioxidant and Anti-Inflammatory Foods
}

\author{
Sirirat Deeseenthum*, Vijitra Luang-In, Supaporn Chunchom
}

\section{Sirirat Deeseenthum*, Vijitra Luang-In, Supaporn Chunchom Natural Antioxidant Innovation Research Unit, Faculty of Technology, Mahasarakham, University, Khamriang Sub-district, Kantarawichai District, Maha Sarakham-44150, THAILAND.}

\section{Correspondence}

Sirirat Deeseenthum

Natural Antioxidant Innovation Research Unit, Faculty of Technology,

Mahasarakham University, Khamriang Sub-district, Kantarawichai District, Maha Sarakham 44150, THAILAND.

Phone No: +66 845168363

E-mail: sirirat.d@msu.ac.th

History

- Submission Date: 10-10-2017

- Review completed: 27-10-2017;

- Accepted Date: 02-11-1207

DOI : 10.5530/pj.2018.1.26

Article Available online

http://www.phcogj.com/v10/i1

Copyright

(C) 2018 Phcog.Net. This is an openaccess article distributed under the terms of the Creative Commons Attribution 4.0 International license.

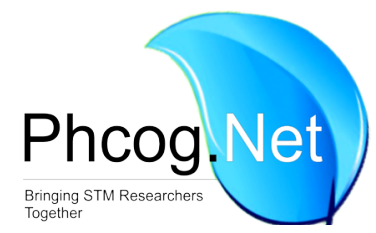

\begin{abstract}
Aims: The characteristics, antioxidant property of Hawm Nil rice (Purple rice), Red Hawm rice (Red rice), Khao Dawk Mali 105 rice (White rice) milk kefirs and mixing of three color rice milk kefir in different ratios were investigated. Then, anti-inflammatory activity of Hawm Nil rice kefir was studied. Methodology: The physiochemical properties, total phenolic compounds and antioxidant activities of these rice milk kefirs were investigated. Anti-inflammatory measurements were performed to study blood chemistry, hematological values and tumor necrosis factor-a (TNF-a) level in colitis rats compared with rats treated with prednisolone (positive control) and cow's milk kefir. Results: All the rice kefir formulas had lower $\mathrm{pH}$ values than the cow's milk kefir. Moreover, they all exhibited no changing viscosity. Lactic acid concentrations increased in cow's milk kefir during 24-48 $\mathrm{h}$. Alcohol concentrations in all the rice formulas increased within 24-48 h, while cow's milk only increased at $72 \mathrm{~h}$. Antioxidant activity, most of the rice milk kefirs had antioxidant activity higher than cow's milk by DPPH assay. In addition, the Hawm Nil rice milk kefir had high antioxidant activity by DPPH assay and FRAP assay. Blood chemistry, hematological values and tumor necrosis factor- $\alpha$ (TNF- $\alpha$ ) levels in colitis rats treated with Hawm Nil rice milk kefir did not differ from those treated with prednisolone and cow's milk kefir. TNF- $\alpha$ in the serum of colitis rats treated with Hawm Nil rice milk kefir was significantly reduced when compared to the PBS buffer. Conclusion:The findings indicated that color rice kefirs may offer protection against chemically induced tissue injury. Hawm Nil rice milk kefir exerted potential antioxidant and anti-inflammatory activities and was safe for human consumption. Other Thai colored rice will be used to develop Thai rice milk kefir products as new and antioxidant-rich beverages and functional foods for human health benefits in the future.
\end{abstract}

Key words: Anti-inflammatory, Antioxidant, Lactic acid, Rice kefir, Thai color rice.

\section{INTRODUCTION}

Nowadays, the lifestyle of Thai people has increased in pace and changes in eating behavior have adversely affected health and the risk of heart attacks and hypertension. The stress of having a busy lifestyle induces free radical release as a cause of cancer, diabetes, mental disorders such as Alzheimer's disease, ${ }^{1}$ ischemic diseases, heart failure, high blood pressure, inflammatory diseases, adult respiratory distress syndrome, organ transplantation, smoking-related diseases, and AIDS. ${ }^{2}$ The prevention of these conditions can be achieved by consuming foods rich in antioxidants. Rice (Oryza sativa L.) was proved to contain several compounds with pharmacological activity previously isolated from brown rice such as $\gamma$-aminobutyric acid (GABA), $\alpha$-tocopherol, $\gamma$-tocopherol, total phenolic compounds (TPC) and flavonoids. ${ }^{3,4,5}$ Therefore, rice and rice products exhibit antioxidant activity. ${ }^{6,78}$ Several scientific reports also indicated that as well as these compounds found in red and black rice, anthocyanins and proanthocyanidins were also found in pigmented rice, offering higher antioxidant activities compared to non-pigmented. ${ }^{4,9,10}$

Kefir is fermented milk produced by groups of lactic acid bacteria (LAB), acetic acid bacteria (AAB) and yeasts. Kefir is gaining popularity in healthconscious consumers in Thailand. It has a slightly sour taste and a small amount of alcohol and can be produced from various kinds of milk such as cow, goat, camel milk, soya milk and rice milk. ${ }^{7,11}$ Fermented milk from kefir has a high antioxidant activity that reduces the accumulation of reactive oxygen species (ROS) including superoxide $\left(\mathrm{O}^{2--}\right)$, hydrogen peroxide $\left(\mathrm{H}_{2} \mathrm{O}_{2}\right)$ and nitric oxide (NO-). ${ }^{12}$ Interestingly, it was found that the antioxidant activity of rice milk kefir was higher than that of cow's milk kefir. ${ }^{6,7}$ McCue and Shetty (2005) suggested that the effects of antioxidants were higher in kefir fed with milk from plant sources as a result of the phenolic compounds in plants. Studies on chemical constituents as well as the effects of Thai rice milk kefir are still limited. Knowledge of the

Cite this article: Deeseenthum S, Luang-In V, Chunchom S. Characteristics of Thai Pigmented Rice Milk Kefirs with Potential as Antioxidant and Anti-Inflammatory Foods. Pharmacog J. 2018;10(1):154-61. 
antioxidant activity of Thai rice milk kefir ${ }^{7}$ and the antioxidant activity of fermented Khao Dawk Mali 105 brown rice by $\mathrm{LAB}^{8}$ is scarce. To enhance the functionality of kefir, a new functional food, Thai pigmented rice milk kefir was developed for health promotion in this work.

However, research describing the pharmacological activity of Thai pigmented rice kefir has not yet been reported. This study, therefore, was aimed to investigate the characteristics, antioxidant properties of different color rice kefirs and determine anti-inflammatory effect of rice kefir compared with cow's milk kefir and medicine (prednisolone).

\section{METHODOLOGY}

\section{Rice samples}

Three color rice varieties, namely, Hawm Nil rice (purple rice), Red Hawm Rice (red rice) and Khao Dawk Mali 105 rice (white rice) were obtained from Selaphum, Roi Et Province, Thailand (2013 harvest season). All rice samples were mixed into the following formulas: Formula I: the rice mixture of purple rice: red rice: white rice was 2.0:2.0:2.0, Formula II was 1.0:2.5:2.5 Formula III was 1.0:3.0:2.0 and Formula IV was 1.5:1.5:3.0. The rice samples were stored in dark plastic bags at a cool temperature $\left(4^{\circ} \mathrm{C}\right)$ before use.

\section{Preparation of rice milk}

All rice samples were paean moisture to dry. Rice was soaked in distilled water $(1: 5 \mathrm{v} / \mathrm{v})$ at room temperature for $2 \mathrm{~h}$. The rice was thoroughly ground using a blender and then filtrated. The rice milk was pasteurized at $70^{\circ} \mathrm{C}$, held at this temperature for $15 \mathrm{~min}$ and then immediately cooled at $4^{\circ} \mathrm{C}$.

\section{Kefir culturing and rice milk fermentation}

The method, with slight modifications, followed Chunchom et al. (2015). ${ }^{14}$ Freeze-dried kefir grain (DC 500 I; Danisco Biolacta, Poland) $10 \mathrm{mg}$ was inoculated into $100 \mathrm{~mL}$ of Lactobacilli de Man, Rogosa, and Sharpe (MRS) at $37^{\circ} \mathrm{C}$ for $24 \mathrm{~h}$ and harvested by centrifugation $(5000 \mathrm{~g}$, $10 \mathrm{~min}$ ) washed and resuspended in sterile saline solution $(0.85 \% \mathrm{NaCl})$. The suspension was diluted with sterile $0.85 \% \mathrm{NaCl}(1: 10 \mathrm{v} / \mathrm{v})$ and then used as kefir starter culture. All the fresh milk (Hawm Nil rice milk, Red Hawm rice milk, Khao Dawk Mali 105 rice milk) were mixed into four pigmented rice milk formulas as already mentioned above at $300 \mathrm{~mL}$ and control was pasteurized cow's milk. Next, $2.5 \%$ (v/v) sucrose syrup $(50 \mathrm{~g} / \mathrm{L})$ and $10 \%(\mathrm{v} / \mathrm{v})$ kefir starter culture was added to the four prepared rice milk formulas and incubated at $25^{\circ} \mathrm{C}$ for $72 \mathrm{~h}$ without shaking. The experiments were conducted in triplicate.

\section{Characteristic of pigmented rice milk kefir Physiochemical properties of color rice milk kefirs}

The $\mathrm{pH}$ values of the kefirs at $0,24,48,72 \mathrm{~h}$ were determined using a digital $\mathrm{pH}$ meter (Ezdo $\mathrm{pH} / \mathrm{mV} / \mathrm{Temp}$ meter PL-600). The viscosity of the sample was determined using a viscometer (Syncherd-Lectric, Brookfield).

\section{Lactic acid and alcohol concentrations determination}

Lactic acid was determined by GC-2014A (Shima Dzu, Japan). The sample or standard solution was injected $1.0 \mu \mathrm{L}$ onto a Rtx-Wax (Restek, USA) column $(30 \mathrm{~mm} \times 0.25 \mathrm{~mm}$ i.d. $\times 0.25 \mu \mathrm{m})$. The column was operated at $60^{\circ} \mathrm{C}$ for $2 \mathrm{~min}$ and then was raised to $200^{\circ} \mathrm{C}$ for $2 \mathrm{~min}$. The $\mathrm{He}$ was used as the carrier at $2.02 \mathrm{~mL} \mathrm{~min}^{-1}$. The injector temperature was $120^{\circ} \mathrm{C}$ and detector temperature was $200^{\circ} \mathrm{C}$. Alcohol analysis was determined by GC-14A (Shima Dzu, Japan) using a PEG column (20M 60/80 Chromasorb Shima Dzu, Japan) with injections of sample $1 \mu \mathrm{L}$. The col- umn temperature was at $80^{\circ} \mathrm{C}$. The injector and detector temperatures were maintained at $120^{\circ} \mathrm{C}$ and $150^{\circ} \mathrm{C}$, respectively. The carrier gas $\left(\mathrm{N}_{2}\right)$

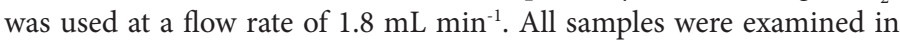
duplicate.

\section{Determination of antioxidant activities \\ Preparation of kefir extract}

Color rice milk kefir products $(10 \mathrm{~mL})$ were filtered with a white cloth to separate kefir grain. After centrifuging the mixture at $10,000 \mathrm{rpm}$ for $10 \mathrm{~min}$ at $4^{\circ} \mathrm{C}$, the samples (liquid portion) were used for further analysis.

\section{Determination of Total Phenolic Compounds}

The amount of total phenolic content in each kefir sample was determined using Folin-Ciocalteu reagent according to Butkhup et al. (2013). ${ }^{16}$ Gallic acid was used as a standard. Each sample solution $(12.5 \mu \mathrm{L})$ was mixed with $12.5 \mu \mathrm{L}$ of distilled water and $12.5 \mu \mathrm{L}$ of $10 \%$ Folin-Ciocalteu reagent. The mixture solution was allowed to stand at room temperature for $6 \mathrm{~min}$. Next, $125 \mu \mathrm{L}$ of $7 \%$ (w/v) sodium carbonate solution and $100 \mu \mathrm{L}$ of distilled water were added. The mixture was left at room temperature for $90 \mathrm{~min}$. The absorbance of each sample was measured at $760 \mathrm{~nm}$ using a microplate reader (ASYS UVM 340, UK) This experiment was carried out in triplicate and the averages of values were calculated. The total phenolic content was analyzed against gallic acid calibration standard curve and expressed as mg GAE/L.

\section{2,2-diphenyl-1-picrylhydrazyl hydrate(DPPH)free radical scavenging assay}

Free radical scavenging activity of the aqueous extract was determined using a stable 2, 2'-diphenyl-1-picrylhydrazyl (DPPH) following a modified method of Chan et al. (2007). ${ }^{17} \mathrm{~A}$ total of $50 \mu \mathrm{L}$ of kefir solution was mixed with $100 \mu \mathrm{L}$ of $0.1 \mu \mathrm{g} / \mathrm{mL}$ DPPH solution. The mixture solution was incubated at room temperature in the dark for $30 \mathrm{~min}$. Absorbance of each sample was measured at $517 \mathrm{~nm}$ using a microplate reader (ASYS UVM 340, UK). The percentage of inhibition was calculated using the following equation:

$$
\text { Inhibition (\%) }=\left[\left(\mathrm{A}_{517 \text { control }}-\mathrm{A}_{517 \text { sample }}\right) / \mathrm{A}_{517 \text { control }}\right] \times 100
$$

Beta hydroxy acid (BHA) dissolved in methanol was used as a positive control. The experiments were performed in triplicate.

\section{Ferric reducing antioxidant power (FRAP) assay}

This was conducted with a modified method described by Benzie and Strain (1999)..$^{18}$ A volume of $20 \mu \mathrm{L}$ from each kefir solution $(0.01 \mathrm{~g} / \mathrm{mL})$ was mixed with $150 \mu \mathrm{L}$ of FRAP solution $(300 \mathrm{mM}$ acetate buffer ( $\mathrm{pH}$ 3.6): $10 \mathrm{mM}$ tripyridyl triazine solution: $20 \mathrm{mM}$ ferric chloride solution (in $40 \mathrm{mM} \mathrm{HCl}$ ) in a ratio of 10: 1: $1 \mathrm{v} / \mathrm{v}$ ). The mixture was mixed well and incubated for $30 \mathrm{~min}$. Absorbance was measured at $595 \mathrm{~nm}$ using a microplate reader (ASYS UVM 340, UK). Samples were measured in triplicate. Ferrous (II) sulfate was used to construct the standard curve. The results were expressed as $\mathrm{mg} \mathrm{Fe}(\mathrm{II}) / \mathrm{L}$.

\section{Experimental animals}

Male Wistar rats (weighing 180-200 g) were purchased from the National Laboratory Animal Center, Mahidol University, Thailand. The rats were kept in an animal laboratory and acclimated for 7 days in environmental conditions $\left(23 \pm 2^{\circ} \mathrm{C}\right.$ and $50-55 \%$ relative humidity under a 12 -h light/ dark cycle). The rats were fed on a standard diet (Perfect Companion Group Co., Ltd.) and water ad libitum. All experimental protocols were maintained in accordance with the Guidelines of Committee Care and Use of Laboratory Animal Research, National Research Council of 
Deeseenthum et al:: Characteristics of Thai Pigmented Rice Milk Kefirs with Potential as Antioxidant and Anti-Inflammatory Foods

Thailand and advice of the Institutional Animal Care and Use Committee, Mahasarakham University, Thailand (ID: 0008/2557).

\section{Kefir powder}

All milk kefir was freeze-dried using SJIA-10N freeze dryer (Shanghai Beiyi Bioequip Information Co., Ltd., China.) at $-55^{\circ} \mathrm{C}$. The freeze-dried kefir was powdered to obtain kefir powder with a mortar and pestle under aseptic condition. Then, all the kefir powders were packed into bottles and the caps were tightened and wrapped with foil. The kefir bottles were kept at $-20^{\circ} \mathrm{C}$ until required for use.

\section{Effect of kefir powder in rat models Experimental design}

The color rice milk kefirs from the previous experiment were all used for studies in rat models. The rats were randomly divided into 7 groups with 6 rats in each:

- $\quad$ Group 1: non-colitis rats received phosphate buffered saline (PBS)

- Group 2: non-colitis rats received Hawm Nil brown milk rice kefir ( $150 \mathrm{mg} / \mathrm{kg}$ dissolved in PBS)

- Group 3: non-colitis rats received cow's milk kefir (150 mg/kg dissolved in PBS)

Group 4: colitis rats received PBS

- Group 5: colitis rats received best brown rice milk kefir (150 mg/kg dissolved in PBS)

- Group 6: colitis rats received cow's milk kefir (150 mg/kg dissolved in PBS)

- Group 7: colitis rats received prednisolone $(5 \mathrm{mg} / \mathrm{kg})$

Colitis rat groups were induced on day 4 by trinitrobenzenesulfonic acid (TNBS) and left for 10 days. Hawm Nil brown rice milk kefir, cow's milk kefir or prednisolone was administered daily to the rats orally between 7-8 am.

\section{Colitis induction}

The rats were colitis induced on day 4 and thereafter. Colitis induction followed the method originally described by Scarminio et al. (2012). ${ }^{19}$ after fasting overnight, the rats were anesthetized with halothane. Under anesthesia, they were given $10 \mathrm{mg}$ of TNBS dissolved in $0.25 \mathrm{~mL}$ of $50 \%$ (v/v) ethanol by means of a Teflon cannula inserted $8 \mathrm{~cm}$ into the anus. During and after TNBS administration, the rats were kept in a headdown position until they recovered from the anesthesia. Rats from the non-colitis group received $0.25 \mathrm{~mL}$ of saline.

\section{Anti-inflammatory activity studies Blood chemistry and hematological values}

At the end of the experiment, the rats were fasted for $24 \mathrm{~h}$, weighed and then euthanized with $50 \mathrm{~mL}$ of chloroform. Blood samples were put into heparinized and non-heparinized tubes. Blood was centrifuged at 1500 $\mathrm{g}$ for $10 \mathrm{~min}$ to separate serum. The serum from the non-heparinized blood was assayed (Stanbio Liqui Color ${ }^{\circledR}$ ) for biochemistry including total protein (TP), blood sugar (BS), blood urea nitrogen (BUN), creatinine (Crea), uric acid (UA), cholesterol (CHO), triglycerides (TG), high density lipoprotein (HDL), low density lipoprotein (LDL), albumin (Alb), globulin (Glob), total bilirubin (TB), aspartate aminotransferase (AST), alanine aminotransferase (ALT), and alkaline phosphatase (ALP). Heparinized blood was used for hematological analysis. Hematological analyses including red blood cell (RBC) count, white blood cell (WBC) count, hematocrit (Hct), hemoglobin $(\mathrm{Hb})$, mean corpuscular volume $(\mathrm{MCV})$, mean corpuscular hemoglobin $(\mathrm{MCH})$, mean corpuscular hemoglobin concentration (MCHC), platelets (Plt), neutrophils (Neu), and lymphocytes (Lym) were performed (StanbioLiquiColor ${ }^{\circledR}$ ).

\section{Tumor necrosis factor-a determination}

TNF- $\alpha$ determination was performed using the Rat TNF- $\alpha$ ELSA (Enzyme-Linked Immunosorbent Assay; Sigma-Aldrich, Inc., USA) kit. The kit was an in vitro enzyme-linked immunosorbent assay for the quantitative measurement of rat TNF- $\alpha$ in cell lysate and tissue lysate. This assay employed an antibody specific for rat TNF- $\alpha$ coated on a 96-well plate. Standards and samples were pipetted into the wells and TNF- $\alpha$ present in a sample was bound to the wells by the immobilized antibody. The wells were washed, and biotinylated anti-rat TNF- $\alpha$ antibody was added. After washing away unbound biotinylated antibody, HRP-conjugated streptavidin was pipetted to the wells. The wells were again washed, a 3,3'5,5'-Tetramethylbenzidine substrate solution was added to the wells and the color was developed in proportion to the amount of TNF- $\alpha$ bound. The stop solution changed the color from blue to yellow, and the intensity of the color was measured at $450 \mathrm{~nm}$.

\section{Statistical analyses}

The data were presented as means \pm SEM and analyzed using one-way ANOVA. The differences among means were detected using Duncan's Multiple Range Test and values of $p \leq 0.05$ were considered statistically significant.

\section{RESULTS AND DISCUSSION}

\section{Acidity and viscosity of milk kefir}

The change in the $\mathrm{pH}$ of pasteurized milk and fermented color rice milk formulas during $0,24,48,72 \mathrm{~h}$ fermentation time is shown in Figure 1. When fermented for $72 \mathrm{~h}, \mathrm{pH}$ values of all milk kefirs slightly decreased. Moreover, all the rice kefir formulas had $\mathrm{pH}$ values (started at $\sim 4.5$ 5.5 , ended at $\sim 3-3.5$ ) lower than cow's milk kefir (started at $\sim 6$, ended at $\sim 4-4.5$ ). The different $\mathrm{pH}$ values between rice milk kefir and cow's milk kefir were possibly caused by the acid produced by predominant microbes which may be different from those in cow's milk kefir. Importantly, the acidity of rice milk kefir was slightly higher than cow's milk kefir and that may be due to higher amounts of sugar in rice than in cow's milk. The $\mathrm{pH}$ values at the starting time $(0 \mathrm{~h})$ of all the rice formulas were different; however, they were not significantly different $(\mathrm{p} \geq 0.05)$ during the fermentation times $(24-72 \mathrm{~h})$. This may be due to similar species of microbes in all the formulas of rice milk kefir, thus producing similar acidity effects.

Viscosity values of milk kefirs are a measure of their resistance to gradual deformation by shear stress or tensile stress. The viscosity values of all the rice milk kefirs did not differ during fermentation processes $(0-72 \mathrm{~h})$. In contrast, the cow's milk kefir had significantly increasing of the viscosity values during fermentation processes Figure 1. These results showed that the cow's milk kefirs had the capacity to separate milk layer from water layer more rapidly than rice milk kefir, and a higher level of solid in cow's milk.

\section{Lactic acid and alcohol concentration}

The lactic acid concentration of all rice milk kefirs did not change until the end of fermentation $(2.20 \pm 0.55 ; \%)$. On the other hand, lactic acid concentration of the cow's milk kefir increased from $2.19 \pm 0.03 ; \%$ at $0 \mathrm{~h}$ to $2.88 \pm 0.0 ; \%$ at $24 \mathrm{~h}$ and to $2.90 \pm 0.06 ; \%$ at $48 \mathrm{~h}$, respectively. At $72 \mathrm{~h}$, thelactic acid concentration decreased to $2.23 \pm 0.00$; \% Table 1 . The result implied that lactose in cow's milk was present in higher amounts than in rice milk, thus causing more lactic acid to form in cow's milk kefir. This result agreed with the $\mathrm{pH}$ value. The hydrolysis and fermentation steps showed different $\mathrm{pH}$ values, and samples considering the $\mathrm{pH}$ value dependence 
of the lactic acid production rate were developed for lactic acid bacteria fermenting whey. ${ }^{19}$

Alcohol concentrations of all rice milk kefirs were insignificantly different at the starting time $(0.002-0.005 ; \%)$. At $24 \mathrm{~h}$, the alcohol concentrations of Hawm Nil brown rice milk, Formula I and IV of rice milk kefir mixtures significantly increased $(0.008 \pm 0.00,0.010 \pm 0.00$ and $0.007 \pm 0.00 ; \%$, respectively) when compared to those at $0 \mathrm{~h}$. At $48 \mathrm{~h}$, the alcohol concentration of Hawm Nil brown rice milk, Formula II and III of rice milk kefir mixtures significantly increased $(0.013 \pm 0.00,0.015 \pm 0.00$ and $0.010 \pm 0.00 ; \%$, respectively) when compared with those at $24 \mathrm{~h}$. At $72 \mathrm{~h}$, the alcohol concentration of cow's milk kefir significantly increased $(0.007 \pm 0.00 ; \%)$ when compared with those at 0,24 and $48 \mathrm{~h}$. The results suggested that the rice milk kefir had rapidly increased in alcohol concentration in a shorter period of time than cow's milk. This may be because of the higher amount of glucose in rice milk than cow's milk. ${ }^{20}$ The fermentation of rice milk kefir by microbes used energy source from glucose first, and thus in the duration $24-48 \mathrm{~h}$ more alcohol was produced when compared to cow's milk kefir. However, the cow's milk kefir produced lower amounts of alcohol when fermentation progressed Table 1.

\section{Total phenolic compounds and antioxidant activities}

The total phenolic compounds (TPC) of the cow's milk, Hawm Nil rice (Purple Rice), Red Hawm rice (Red rice) and Khao Dawk Mali 105 rice (White rice) milk kefirs significantly increased ( $\mathrm{p} \leq 0.05)$ during 48-72 h of the fermentation process Table 2. Moreover, the TPC of all the formulas of rice milk kefirs rapidly increased compared to cow's milk kefir and non-mixing rice milk kefir. The TPC of all the mixing formulas of rice milk kefirs increased within $24 \mathrm{~h}$ and were also significantly different $(\mathrm{p} \leq 0.05)$ from the cow's milk kefir and the three non-mixing rice milks

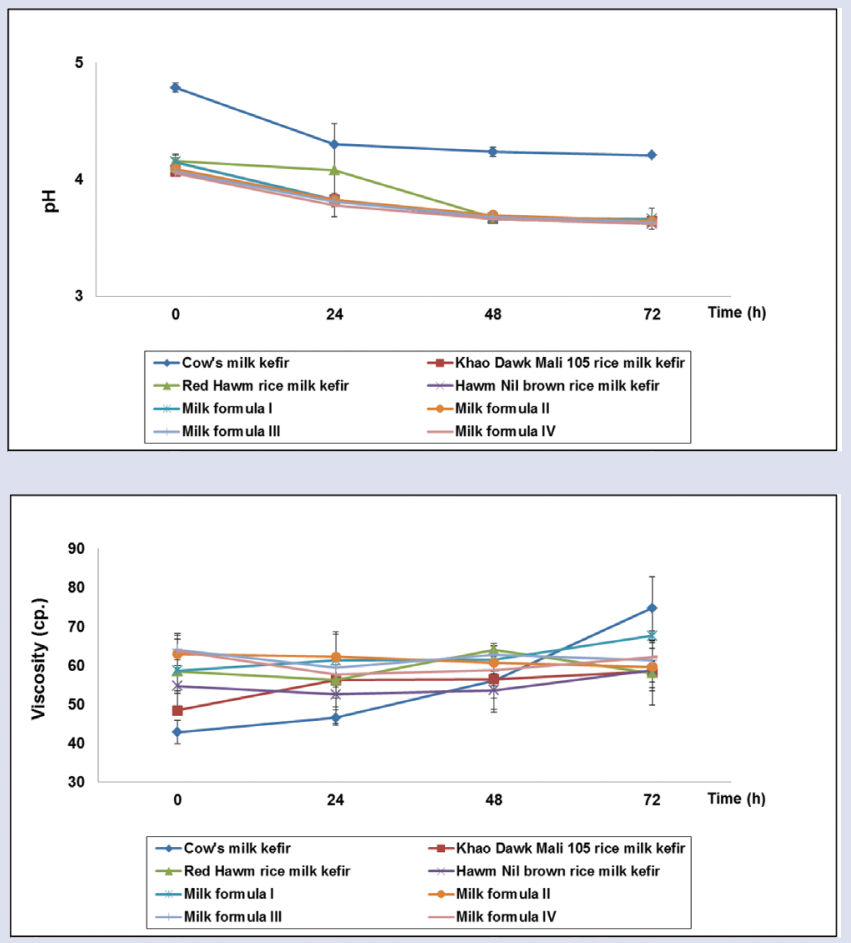

Figure 1: Changes in $\mathrm{pH}$ and viscosity in the milk kefirs over $72 \mathrm{~h}$ fermentation period. at $24 \mathrm{~h}$ Table 2 . However, all the treatments were insignificantly different in TPC levels at $48 \mathrm{~h}$, surprisingly, the TPC of Hawm Nil rice and cow's milk kefir were highest and significantly different from other treatments at $72 \mathrm{~h}$. Phenolic compounds have redox properties which allow them to act as antioxidants. ${ }^{21}$ As their free radical scavenging ability is facilitated by their hydroxyl groups, the total phenolic concentration could be used as a basis for rapid screening of antioxidant activity. ${ }^{22}$ In addition, our previous study found that Hawm Nil rice (dark purple rice) had the highest TPC when compared with other color rice and cow's milk. ${ }^{6}$ Other research of pigment rice also reported that dark purple or black rice had high TPC compared to other color rice without fermentation. ${ }^{4}$

\section{Antioxidant activities}

The antioxidant activity of kefirs was determined using 2, 2' -diphenyl1-picrylhydrazyl (DPPH) assay and ferric reducing antioxidant power (FRAP) assay. Plants rich in secondary metabolites including phenolics, flavonoids and carotenoids have antioxidant activity due to their redox properties and chemical structures (Baba and Malik, 2015). Results showed that the Hawm Nil rice milk kefir had higher antioxidant activity (33.32 \pm 6.48 and $1.33 \pm 0.60 ; \%$; respectively) than cow's milk kefir at $72 \mathrm{~h}$ Table 3. Moreover, most of the rice milk kefir formulas had antioxidant activity higher than cow's milk by DPPH assay. This result was also supported by our previous work concerning the antioxidant activity of rice. ${ }^{6}$ However, the FRAP assay showed that rice milk formula IV (mixing of Khao Dawk Mali 105 rice, Hawm Nil rice and Red Hawm rice in a ratio of 1.5:1.5:3.0) had higher antioxidant activity than the other rice milk kefirs; however, this was not significantly different from that of cow's milk kefir. Free radicals have been implicated in the development of many disorders including cancer, neuro-degeneration and inflammation. ${ }^{23}$ Hence, the result of TPC and antioxidant activity of rice milk kefir indicated that Hawm Nil rice kefir can be used as an antioxidant.

\section{Anti-inflammatory effect of kefirs in colitis rats Blood biochemistry and hematological values}

The colitis rats that received PBS (control) had significantly $(p \leq 0.05)$ increased BS, BUN, UA, and TP when compared to the non-colitis rats Table 4. Moreover, the colitis rats treated with rice milk kefir produced a release of BS, BUN, UA, and TP to normal levels, similar to prednisolone and cow's kefir powder. In addition, the colitis rats that received PBS also exhibited significantly $(p \leq 0.05)$ increased ALT and ALP levels, and decreased AST when compared to the non-colitis rats Table 5. However, the colitis rats treated with rice milk kefir exerted a release of ALT, ALP, and AST to normal levels.

The colitis rats treated with rice milk kefirs and the non-colitis rats (control) did not differ in lipid profiles Table 6.

The hematological determination found that the colitis rats treated with rice milk kefir and cow's milk kefir had increased WBC and Neu while $\mathrm{RBC}, \mathrm{Hb}$ and Hct levels decreased when compared with the colitis rats treated with prednisolone. In addition, the colitis rats treated with rice and cow's milk kefirs did not differ in hematological values when compared to the non-colitis rats Table 7 .

In the literature, blood biochemistries of BS, BUN, CREA, UA, TP, Alb, and Glob were involved in renal function and AST, ALT, and ALP enzymes were involved in hepatic function. Thus, the changing levels of these enzymes induced renal and hepatic dysfunctions. ${ }^{24}$ The colitis rats treated with rice milk kefir produced BS, BUN, UA and TP at normal levels like the effects caused by prednisolone and cow's milk kefir. In addition, the colitis rats that received PBS had significantly $(p \leq 0.05)$ increased ALT and ALP level and decreased AST compared to the non-colitis rats. However, the colitis rats exerted releases of ALT, ALP and AST at normal levels when treated with rice milk kefirs. 
Deeseenthum et al:: Characteristics of Thai Pigmented Rice Milk Kefirs with Potential as Antioxidant and Anti-Inflammatory Foods

Table 1: Lactic acid and alcohol concentration production of milk kefirs

\begin{tabular}{ccccccccc}
\hline \multirow{2}{*}{ Treatments } & \multicolumn{3}{c}{ Lactic acid concentration (\%) } & \multicolumn{4}{c}{ Alcohol concentration (\%) } \\
\cline { 2 - 9 } & \multicolumn{3}{c}{ Fermentation time (h) } & \multicolumn{3}{c}{ Fermentation time (h) } \\
\hline & 0 & 24 & 48 & 72 & 0 & 24 & 48 \\
\hline Cow's milk & $2.19 \pm 0.03^{\mathrm{b}}$ & $2.88 \pm 0.07^{\mathrm{Aa}}$ & $2.90 \pm 0.06^{\mathrm{Aa}}$ & $2.23 \pm 0.00^{\mathrm{b}}$ & $0.003 \pm 0.00^{\mathrm{b}}$ & $0.003 \pm 0.00^{\mathrm{Cb}}$ & $0.003 \pm 0.00^{\mathrm{Cb}}$ & $0.007 \pm 0.00^{\mathrm{BCa}}$ \\
Khao Dawk Mali 105 & $2.25 \pm 0.01$ & $2.21 \pm 0.01^{\mathrm{B}}$ & $2.21 \pm 0.03^{\mathrm{B}}$ & $2.21 \pm 0.02$ & $0.004 \pm 0.00$ & $0.004 \pm 0.00^{\mathrm{C}}$ & $0.003 \pm 0.00^{\mathrm{C}}$ & $0.003 \pm 0.00^{\mathrm{C}}$ \\
rice milk & & & & & & & \\
Red Hawm rice milk & $2.21 \pm 0.03$ & $2.20 \pm 0.02^{\mathrm{B}}$ & $2.18 \pm 0.00^{\mathrm{B}}$ & $2.18 \pm 0.00$ & $0.002 \pm 0.00^{\mathrm{b}}$ & $0.005 \pm 0.00^{\mathrm{BCa}}$ & $0.002 \pm 0.00^{\mathrm{Cb}}$ & $0.005 \pm 0.00^{\mathrm{Ca}}$ \\
Hawm Nil brown rice milk & $2.22 \pm 0.02$ & $2.18 \pm 0.00^{\mathrm{B}}$ & $2.24 \pm 0.03^{\mathrm{B}}$ & $2.26 \pm 0.05$ & $0.005 \pm 0.00^{\mathrm{C}}$ & $0.008 \pm 0.00^{\mathrm{ABb}}$ & $0.013 \pm 0.00^{\mathrm{Aa}}$ & $0.013 \pm 0.00^{\mathrm{ABa}}$ \\
Milk formula I & $2.20 \pm 0.02$ & $2.23 \pm 0.02^{\mathrm{B}}$ & $2.25 \pm 0.01^{\mathrm{B}}$ & $2.23 \pm 0.02$ & $0.004 \pm 0.00^{\mathrm{C}}$ & $0.010 \pm 0.00^{\mathrm{Ab}}$ & $0.010 \pm 0.00^{\mathrm{ABb}}$ & $0.014 \pm 0.00^{\mathrm{ABa}}$ \\
Milk formula II & $2.25 \pm 0.04$ & $2.22 \pm 0.03^{\mathrm{B}}$ & $2.26 \pm 0.00^{\mathrm{B}}$ & $2.21 \pm 0.01$ & $0.005 \pm 0.00^{\mathrm{b}}$ & $0.007 \pm 0.00^{\mathrm{Bb}}$ & $0.015 \pm 0.00^{\mathrm{Aa}}$ & $0.016 \pm 0.00^{\mathrm{Aa}}$ \\
Milk formula III & $2.20 \pm 0.01$ & $2.21 \pm 0.05^{\mathrm{B}}$ & $2.25 \pm 0.01^{\mathrm{B}}$ & $2.22 \pm 0.01$ & $0.004 \pm 0.00^{\mathrm{b}}$ & $0.005 \pm 0.00^{\mathrm{BCb}}$ & $0.010 \pm 0.00^{\mathrm{ABa}}$ & $0.012 \pm 0.00^{\mathrm{Ba}}$ \\
Milk formula IV & $2.21 \pm 0.00$ & $2.24 \pm 0.01^{\mathrm{B}}$ & $2.25 \pm 0.01^{\mathrm{B}}$ & $2.26 \pm 0.01$ & $0.003 \pm 0.00^{\mathrm{C}}$ & $0.007 \pm 0.00^{\mathrm{Bb}}$ & $0.008 \pm 0.00^{\mathrm{Bab}}$ & $0.011 \pm 0.00^{\mathrm{Ba}}$ \\
\hline
\end{tabular}

Mean values within each column with different superscripts (upper case) and mean values within each row with different superscripts (lower case) are significantly different, Duncan's test at $p \leq 0.05$.

Remarks: Milk formula I was the mixture of Khaw Dawk Mali 105, Hawm Nil rice and Red Hawm rice in a ratio of $2.0: 2.0: 2.0$

Milk formula II was the mixture of Khaw Dawk Mali 105, Hawm Nil rice and Red Hawm rice in a ratio of $1.0: 2.5: 2.5$

Milk formula III was the mixture of Khaw Dawk Mali 105, Hawm Nil rice and Red Hawm rice in a ratio of $1.0: 3.0: 2.0$

Milk formula IV was the mixture of Khaw Dawk Mali 105, Hawm Nil rice and Red Hawm rice in a ratio of $1.5: 1.5: 3.0$

Table 2: Total phenolic compound in milk kefirs over $72 \mathrm{~h}$

\begin{tabular}{|c|c|c|c|c|}
\hline \multirow{3}{*}{ Treatments } & \multicolumn{4}{|c|}{ Total phenolic compound (mg GAE/L) } \\
\hline & \multicolumn{4}{|c|}{ Fermentation time (h) } \\
\hline & 0 & 24 & 48 & 72 \\
\hline Cow’s milk & $243.93 \pm 10.61^{\mathrm{Ab}}$ & $203.57 \pm 36.37^{\mathrm{CDb}}$ & $279.64 \pm 53.03^{\text {Bab }}$ & $367.50 \pm 28.79^{\mathrm{Aa}}$ \\
\hline Khao Dawk Mali 105 's milk & $252.86 \pm 7.07^{\mathrm{Ab}}$ & $243.93 \pm 18.69^{\mathrm{Cb}}$ & $321.79 \pm 42.93^{\mathrm{Aa}}$ & $290.00 \pm 12.12^{\mathrm{BCa}}$ \\
\hline Red Hawm rice milk & $250.71 \pm 18.18^{\mathrm{Ab}}$ & $179.64 \pm 10.61^{\mathrm{Dc}}$ & $323.21 \pm 17.68^{\mathrm{Aa}}$ & $319.29 \pm 47.48^{\mathrm{Ba}}$ \\
\hline Hawm Nil brown rice milk & $256.43 \pm 95.97^{\mathrm{Ab}}$ & $183.57 \pm 6.06^{\mathrm{Dc}}$ & $261.43 \pm 42.43^{\mathrm{Bb}}$ & $375.36 \pm 102.53^{\mathrm{Aa}}$ \\
\hline Milk formula I & $195.00 \pm 38.39^{\mathrm{Bc}}$ & $304.29 \pm 89.90^{\mathrm{Bb}}$ & $324.64 \pm 71.21^{\mathrm{Aa}}$ & $198.93 \pm 187.38^{\mathrm{Cc}}$ \\
\hline Milk formula II & $161.07 \pm 28.97^{\mathrm{Bc}}$ & $323.93 \pm 0.51^{\mathrm{ABab}}$ & $358.22 \pm 33.84^{\mathrm{Aa}}$ & $287.14 \pm 53.54^{\mathrm{BCb}}$ \\
\hline Milk formula III & $234.46 \pm 0.50^{\mathrm{Ab}}$ & $361.07 \pm 81.32^{\mathrm{Aa}}$ & $344.29 \pm 21.21^{\mathrm{Aa}}$ & $264.29 \pm 27.27^{\mathrm{BCb}}$ \\
\hline Milk formula IV & $177.50 \pm 7.58^{\mathrm{Bc}}$ & $312.50 \pm 198.49^{\mathrm{ABb}}$ & $319.64 \pm 97.48^{\mathrm{Ab}}$ & $330.00 \pm 85.86^{\mathrm{Ba}}$ \\
\hline
\end{tabular}

Mean values within each column with different superscripts (upper case) and mean values within each row with different superscripts (lower case) are significantly different, Duncan's test at $\mathrm{p} \leq 0.05$.

Remarks: Milk formula I was the mixture of Khaw Dawk Mali 105, Hawm Nil rice and Red Hawm rice in a ratio of $2.0: 2.0: 2.0$

Milk formula II was the mixture of Khaw Dawk Mali 105, Hawm Nil rice and Red Hawm rice in a ratio of $1.0: 2.5: 2.5$

Milk formula III was the mixture of Khaw Dawk Mali 105, Hawm Nil rice and Red Hawm rice in a ratio of $1.0: 3.0: 2.0$

Milk formula IV was the mixture of Khaw Dawk Mali 105, Hawm Nil rice and Red Hawm rice in a ratio of $1.5: 1.5: 3.0$

\section{Tumor necrosis factor-a (TNF- $a$ ) level}

Tumor necrosis factor- $\alpha$ (TNF- $\alpha$ ) is secreted by macrophages, monocytes, neutrophils, T cells, and NK cells following their stimulation by bacterial lipopolysaccharides. TNF- $\alpha$ shows a wide spectrum of biological activities. It causes cytolysis and cytostasis of many tumor cell lines in vitro. Within hours after injection, TNF- $\alpha$ leads to the destruction of small blood vessels within malignant tumors. TNF- $\alpha$ also enhances phagocytosis and cytotoxicity in neutrophilic granulocytes, and modulates the expression of many other proteins. ${ }^{25}$

The TNF- $\alpha$ level in serum of the colitis rats that received PBS (negative control) was highest. However, the colitis rats treated with rice and cow's milk kefirs gave reduced TNF- $\alpha$ level compared to the control Table 8.

The increased production of pro-inflammatory cytokines is thought to be a pivotal factor in the pathogenesis of ulcerative colitis (UC). It is accepted that TNF- $\alpha$ may be particularly important for inducing and sustaining intestinal inflammation in UC. Many studies have shown that TNF- $\alpha$ is expressed in human gastrointestinal mucosa, with the expression strongly enhanced in the inflammatory course of UC. Enhanced production of TNF- $\alpha$ may induce some key enzymes of the inflammation cascade and neutrophil chemotaxis. TNF- $\alpha$ can also induce more production of nitric oxide (NO) and inducible nitric oxide synthase (iNOS). ${ }^{26}$

Although the TNF- $\alpha$ level in serum of the colitis rats that received PBS was highest, the colitis rats treated with rice and cow's milk kefirs also produced TNF- $\alpha$ at a lower level when compared to the control. Moreover, Chunchom et al. (2017) $)^{6}$ found that brown rice kefir powders had no sub-chronic toxicity in Wistar rats when the rats were given rice kefir 
Deeseenthum et al:: Characteristics of Thai Pigmented Rice Milk Kefirs with Potential as Antioxidant and Anti-Inflammatory Foods

Table 3: Antioxidant activity form DPPH and FRAP assays in milk kefirs over $72 \mathrm{~h}$

\begin{tabular}{|c|c|c|c|c|c|c|c|c|}
\hline \multirow{3}{*}{ Treatments } & \multicolumn{4}{|c|}{ DPPH (\% free radical scavenging) } & \multicolumn{4}{|c|}{ FRAP $\left(\mathrm{mg} \mathrm{FeSO}_{4} / \mathrm{L}\right)$} \\
\hline & \multicolumn{4}{|c|}{ Fermentation time $(\mathrm{h})$} & \multicolumn{4}{|c|}{ Fermentation time (h) } \\
\hline & 0 & 24 & 48 & 72 & 0 & 24 & 48 & 72 \\
\hline Cow's milk & $27.21 \pm 0.07^{\mathrm{Bb}}$ & $24.26 \pm 0.22^{\mathrm{Db}}$ & $38.05 \pm 7.82^{\mathrm{BCa}}$ & $27.53 \pm 3.94^{\mathrm{Cb}}$ & $2.13 \pm 0.37^{\text {Aa }}$ & $1.80 \pm 0.64^{\mathrm{Aab}}$ & $2.06 \pm 0.93^{\mathrm{Aa}}$ & $1.25 \pm 0.33^{\mathrm{ABb}}$ \\
\hline $\begin{array}{l}\text { Khao Dawk Mali } 105 \\
\text { 's milk }\end{array}$ & $26.11 \pm 1.04^{\mathrm{Bb}}$ & $38.79 \pm 2.31^{\mathrm{BCa}}$ & $37.47 \pm 3.55^{\mathrm{BCa}}$ & $25.63 \pm 1.56^{\mathrm{Cb}}$ & $1.93 \pm 0.12^{\mathrm{ABa}}$ & $1.67 \pm 0.13^{\mathrm{ABb}}$ & $1.60 \pm 0.12^{\mathrm{AB}}$ & $1.16 \pm 0.33^{\mathrm{ABb}}$ \\
\hline Red Hawm rice milk & $28.05 \pm 2.16^{\mathrm{Bb}}$ & $31.16 \pm 2.23^{\mathrm{Cab}}$ & $40.00 \pm 7.86^{\mathrm{Ba}}$ & $28.05 \pm 4.09^{\mathrm{Cb}}$ & $1.45 \pm 1.51^{\mathrm{BCa}}$ & $1.19 \pm 0.34^{\mathrm{Bab}}$ & $1.01 \pm 0.43^{\mathrm{Bb}}$ & $0.88 \pm 0.29^{\mathrm{Bb}}$ \\
\hline $\begin{array}{l}\text { Hawm Nil brown rice } \\
\text { milk }\end{array}$ & $42.53 \pm 8.63^{\mathrm{ABa}}$ & $34.95 \pm 0.30^{\mathrm{Cb}}$ & $38.11 \pm 4.14^{\text {BCab }}$ & $33.32 \pm 6.48^{\mathrm{BCb}}$ & $1.53 \pm 0.93^{\mathrm{Bab}}$ & $1.75 \pm 1.45^{\mathrm{Aa}}$ & $1.38 \pm 1.07^{\mathrm{Bab}}$ & $1.33 \pm 0.60^{\mathrm{Ab}}$ \\
\hline Milk formula I & $40.58 \pm 10.79^{\mathrm{ABa}}$ & $48.84 \pm 8.19^{\mathrm{Ba}}$ & $35.90 \pm 11.76^{\mathrm{BCb}}$ & $31.32 \pm 1.86^{\mathrm{BCb}}$ & $1.05 \pm 0.18^{\mathrm{Ca}}$ & $0.88 \pm 0.11^{\mathrm{BCab}}$ & $0.80 \pm 0.22^{\mathrm{BCb}}$ & $0.70 \pm 0.07^{\mathrm{BCb}}$ \\
\hline Milk formula II & $68.32 \pm 6.85^{\mathrm{Aa}}$ & $32.11 \pm 5.36^{\mathrm{Cc}}$ & $29.90 \pm 1.93^{\mathrm{Cc}}$ & $59.42 \pm 4.88^{\mathrm{Ab}}$ & $0.66 \pm 0.14^{\mathrm{C}}$ & $0.50 \pm 0.07^{\mathrm{C}}$ & $0.52 \pm 0.12^{\mathrm{C}}$ & $0.63 \pm 0.06^{\mathrm{C}}$ \\
\hline Milk formula III & $59.47 \pm 9.35^{\mathrm{Aa}}$ & $31.05 \pm 0.00^{\mathrm{Cc}}$ & $46.53 \pm 5.06^{\mathrm{Bb}}$ & $49.79 \pm 5.66^{\mathrm{Bab}}$ & $1.06 \pm 0.36^{\mathrm{Cab}}$ & $1.52 \pm 1.34^{\mathrm{ABa}}$ & $0.97 \pm 0.51^{\mathrm{BCb}}$ & $0.86 \pm 0.34^{\mathrm{Bb}}$ \\
\hline Milk formula IV & $51.11 \pm 11.98^{\mathrm{ABc}}$ & $65.90 \pm 0.00^{\mathrm{Aa}}$ & $60.95 \pm 2.18^{\mathrm{Ab}}$ & $61.05 \pm 3.57^{\mathrm{Ab}}$ & $2.14 \pm 0.51^{\mathrm{Aab}}$ & $1.67 \pm 0.61^{\mathrm{ABb}}$ & $2.30 \pm 0.13^{\mathrm{Aa}}$ & $1.41 \pm 0.42^{\mathrm{Ab}}$ \\
\hline
\end{tabular}

Mean values within each column with different superscripts (upper case) and mean values within each row with different superscripts (lower case) are significantly different, Duncan's test at $\mathrm{p} \leq 0.05$.

Remarks: Milk formula I was the mixture of Khaw Dawk Mali 105, Hawm Nil rice and Red Hawm rice in a ratio of $2.0: 2.0: 2.0$ Milk formula II was the mixture of Khaw Dawk Mali 105, Hawm Nil rice and Red Hawm rice in a ratio of $1.0: 2.5: 2.5$ Milk formula III was the mixture of Khaw Dawk Mali 105, Hawm Nil rice and Red Hawm rice in a ratio of $1.0: 3.0: 2.0$ Milk formula IV was the mixture of Khaw Dawk Mali 105, Hawm Nil rice and Red Hawm rice in a ratio of $1.5: 1.5: 3.0$

Table 4: Blood biochemistry; BS, BUN, CREA, UA, TP, Alb, and Glob in experimental rat models with different treatments

\begin{tabular}{|c|c|c|c|c|c|c|c|}
\hline Groups & $\begin{array}{c}\text { BS } \\
(\mathrm{mg} / \mathrm{dl})\end{array}$ & $\begin{array}{c}\text { BUN } \\
(\mathrm{mg} / \mathrm{dl})\end{array}$ & CREA (mg/dl) & $\begin{array}{c}\text { UA } \\
\text { (mg/dl) }\end{array}$ & $\begin{array}{c}\text { TP } \\
(g / d l)\end{array}$ & $\begin{array}{c}\text { Alb } \\
(g / d l)\end{array}$ & $\begin{array}{l}\text { Glob } \\
\text { (g/dl) }\end{array}$ \\
\hline \multicolumn{8}{|l|}{ Non-colitis rats } \\
\hline PBS & $268.70 \pm 2.96^{\mathrm{a}}$ & $21.01 \pm 0.96^{\mathrm{a}}$ & $0.95 \pm 0.04^{\mathrm{a}}$ & $2.80 \pm 0.44^{\mathrm{a}}$ & $6.05 \pm 0.10^{\mathrm{a}}$ & $2.90 \pm 0.08^{\mathrm{a}}$ & $2.61 \pm 0.40^{\mathrm{a}}$ \\
\hline HNKP & $255.61 \pm 1.90^{a}$ & $20.06 \pm 1.01^{\mathrm{a}}$ & $0.96 \pm 0.06^{\mathrm{a}}$ & $2.75 \pm 0.73^{\mathrm{a}}$ & $6.03 \pm 0.11^{\mathrm{a}}$ & $2.98 \pm 0.10^{\mathrm{a}}$ & $2.65 \pm 0.55^{\mathrm{a}}$ \\
\hline СMKP & $266.50 \pm 1.08^{\mathrm{a}}$ & $21.05 \pm 0.86^{\mathrm{a}}$ & $0.94 \pm 0.74^{\mathrm{a}}$ & $2.81 \pm 0.72^{\mathrm{a}}$ & $6.05 \pm 0.14^{\mathrm{a}}$ & $2.80 \pm 0.22^{\mathrm{a}}$ & $2.64 \pm 0.62^{\mathrm{a}}$ \\
\hline \multicolumn{8}{|l|}{ Colitis rats } \\
\hline PBS & $298.25 \pm 3.54^{\mathrm{b}}$ & $25.90 \pm 0.67^{\mathrm{b}}$ & $0.87 \pm 0.08^{\mathrm{a}}$ & $3.15 \pm 0.40^{\mathrm{b}}$ & $6.37 \pm 1.22^{\mathrm{b}}$ & $2.92 \pm 0.14^{\mathrm{a}}$ & $2.70 \pm 0.11^{\mathrm{a}}$ \\
\hline HNKP & $265.40 \pm 2.06^{\mathrm{a}}$ & $21.01 \pm 0.97^{\mathrm{a}}$ & $0.95 \pm 0.02^{\mathrm{a}}$ & $2.70 \pm 0.90^{\mathrm{a}}$ & $6.09 \pm 0.15^{\mathrm{a}}$ & $2.88 \pm 0.87^{\mathrm{a}}$ & $2.62 \pm 0.21^{\mathrm{a}}$ \\
\hline СMКР & $277.67 \pm 1.34^{\mathrm{a}}$ & $21.12 \pm 1.63^{\mathrm{a}}$ & $0.95 \pm 0.00^{\mathrm{a}}$ & $2.67 \pm 0.81^{a}$ & $6.00 \pm 0.17^{\mathrm{a}}$ & $2.97 \pm 0.13^{\mathrm{a}}$ & $2.62 \pm 0.33^{\mathrm{a}}$ \\
\hline Prednisolone & $267.50 \pm 0.98^{\mathrm{a}}$ & $21.15 \pm 1.60^{\mathrm{a}}$ & $0.94 \pm 0.07^{\mathrm{a}}$ & $2.80 \pm 0.70^{\mathrm{a}}$ & $6.04 \pm 0.11^{\mathrm{a}}$ & $2.85 \pm 0.21^{\mathrm{a}}$ & $2.61 \pm 0.67^{\mathrm{a}}$ \\
\hline
\end{tabular}

Mean values within each column with different superscripts are significantly different, Duncan's test at $p \leq 0.05$. BS= blood sugar; $B U N=$ blood urea nitrogen; $\mathrm{CREA}=$ creatinine; $\mathrm{UA}=$ uric acid $\mathrm{TP}=$ total serum protein; $\mathrm{Alb}=$ albumin; Glob = globulin.

Table 5: Blood biochemistry; AST, ALT, and ALP enzymes in experimental rat models with different treatments

\begin{tabular}{cccc}
\hline Groups & $\begin{array}{c}\text { AST } \\
(\mathrm{U} / \mathrm{L})\end{array}$ & $\begin{array}{c}\text { ALT } \\
(\mathrm{U} / \mathrm{L})\end{array}$ & $\begin{array}{c}\text { ALP } \\
(\mathrm{U} / \mathrm{L})\end{array}$ \\
\hline Non-colitis & & & \\
PBS & $128.60 \pm 6.57^{\mathrm{c}}$ & $47.67 \pm 1.53^{\mathrm{ab}}$ & $94.67 \pm 6.60^{\mathrm{a}}$ \\
HNKP & $124.50 \pm 8.63^{\mathrm{c}}$ & $46.67 \pm 1.57^{\mathrm{a}}$ & $93.82 \pm 8.44^{\mathrm{a}}$ \\
CMKP & $126.44 \pm 5.55^{\mathrm{c}}$ & $45.33 \pm 0.98^{\mathrm{a}}$ & $93.90 \pm 7.64^{\mathrm{a}}$ \\
Colitis & & & \\
PBS & $68.47 \pm 7.33^{\mathrm{a}}$ & $78.67 \pm 1.44^{\mathrm{c}}$ & $136.65 \pm 5.33^{\mathrm{b}}$ \\
HNKP & $115.10 \pm 6.67^{\mathrm{bc}}$ & $56.67 \pm 1.43^{\mathrm{b}}$ & $93.67 \pm 8.24^{\mathrm{a}}$ \\
CMKP & $116.50 \pm 7.58^{\mathrm{bc}}$ & $55.48 \pm 1.21^{\mathrm{b}}$ & $94.20 \pm 7.41^{\mathrm{a}}$ \\
Prednisolone & $117.10 \pm 5.80^{\mathrm{bc}}$ & $56.89 \pm 1.60^{\mathrm{b}}$ & $93.85 \pm 8.55^{\mathrm{a}}$ \\
\hline
\end{tabular}

Mean values within each column with different superscripts are significantly different, Duncan's test at $p \leq 0.05$. AST $=$ serum aspartate aminotransferase; $\mathrm{ALT}=$ serum alanine aminotransferase; $\mathrm{ALP}=$ alkaline phosphatase.
Table 6: Cholesterol (CHO), triglycerides (TG), high density lipoprotein $(H D L)$ and low density lipoprotein (LDL) in experimental rat models with different treatments

\begin{tabular}{ccccc}
\hline \multirow{2}{*}{ Groups } & \multicolumn{4}{c}{ Lipid profiles (mg/dl) } \\
\cline { 2 - 5 } & CHO & TG & HDL & LDL \\
\hline Non-colitis & & & & \\
PBS & $52.12 \pm 2.33$ & $148.15 \pm 4.89$ & $17.53 \pm 0.67$ & $28.11 \pm 1.76$ \\
HNKP & $51.67 \pm 1.37$ & $146.22 \pm 5.40$ & $18.12 \pm 0.45$ & $27.15 \pm 1.42$ \\
CMKP & $51.88 \pm 2.11$ & $147.18 \pm 5.88$ & $17.69 \pm 0.92$ & $28.02 \pm 1.54$ \\
Colitis & & & & \\
PBS & $51.94 \pm 0.98$ & $151.01 \pm 1.46$ & $17.00 \pm 0.25$ & $27.51 \pm 0.98$ \\
HNKP & $50.17 \pm 1.56$ & $146.17 \pm 3.67$ & $17.77 \pm 0.60$ & $27.76 \pm 1.70$ \\
CMKP & $51.18 \pm 2.41$ & $147.37 \pm 5.83$ & $17.43 \pm 0.68$ & $28.17 \pm 1.77$ \\
Prednisolone & $51.19 \pm 2.52$ & $148.10 \pm 2.91$ & $17.73 \pm 0.55$ & $27.32 \pm 1.98$ \\
\hline
\end{tabular}


Deeseenthum et al:: Characteristics of Thai Pigmented Rice Milk Kefirs with Potential as Antioxidant and Anti-Inflammatory Foods

Table 7: Hematological values in experimental rat models with different treatments

\begin{tabular}{|c|c|c|c|c|c|c|c|}
\hline Groups & $\begin{array}{c}\text { WBC } \\
\left(10^{3} \text { cell } / \mathrm{mm}^{3}\right)\end{array}$ & $\begin{array}{c}\text { RBC } \\
\left(10^{6} \text { cell } / \mathrm{mm}^{3}\right)\end{array}$ & $\begin{array}{l}\mathrm{Hb} \\
(\mathrm{g} / \mathrm{dl})\end{array}$ & $\begin{array}{l}\text { Hct } \\
\text { (\%) }\end{array}$ & $\begin{array}{c}\text { Plt } \\
\left(10^{3} \text { cell } / \mathrm{mm}^{3}\right)\end{array}$ & $\begin{array}{l}\mathrm{Neu} \\
(\%)\end{array}$ & $\begin{array}{l}\text { Lym } \\
\text { (\%) }\end{array}$ \\
\hline \multicolumn{8}{|l|}{ Non-colitis } \\
\hline PBS & $7.33 \pm 0.86^{a}$ & $10.05 \pm 0.42^{\mathrm{b}}$ & $17.15 \pm 0.56^{\mathrm{b}}$ & $51.83 \pm 1.62^{\mathrm{b}}$ & $808.17 \pm 25.15^{\mathrm{a}}$ & $19.17 \pm 2.84^{\mathrm{a}}$ & $78.33 \pm 3.86^{\circ}$ \\
\hline HNKP & $7.35 \pm 0.77^{a}$ & $9.67 \pm 0.25^{b}$ & $16.70 \pm 0.52^{b}$ & $51.00 \pm 1.68^{\mathrm{b}}$ & $866.50 \pm 31.20^{\mathrm{a}}$ & $18.75 \pm 2.24^{\mathrm{a}}$ & $77.25 \pm 1.65^{a}$ \\
\hline CMKP & $7.13 \pm 0.88^{\mathrm{a}}$ & $9.73 \pm 0.41^{b}$ & $16.87 \pm 0.46^{\mathrm{b}}$ & $51.00 \pm 1.57^{\mathrm{b}}$ & $888.50 \pm 37.04^{\mathrm{a}}$ & $20.83 \pm 2.87^{\mathrm{a}}$ & $76.83 \pm 2.62^{a}$ \\
\hline \multicolumn{8}{|l|}{ Colitis } \\
\hline PBS & $15.42 \pm 0.28^{\mathrm{b}}$ & $8.76 \pm 0.13^{\mathrm{a}}$ & $14.52 \pm 0.23^{\mathrm{a}}$ & $46.33 \pm 0.76^{a}$ & $923.17 \pm 24.11^{\mathrm{a}}$ & $48.83 \pm 1.01^{\mathrm{b}}$ & $80.83 \pm 1.25^{\circ}$ \\
\hline HNKP & $7.34 \pm 0.56^{\mathrm{a}}$ & $10.04 \pm 0.40^{\mathrm{b}}$ & $17.18 \pm 0.57^{b}$ & $51.80 \pm 1.02^{\mathrm{b}}$ & $817.11 \pm 25.15^{\mathrm{a}}$ & $18.57 \pm 2.64^{\mathrm{a}}$ & $77.63 \pm 1.46^{a}$ \\
\hline СMKР & $7.15 \pm 0.87^{a}$ & $9.75 \pm 0.58^{b}$ & $16.88 \pm 0.41^{\mathrm{b}}$ & $51.03 \pm 1.51^{\mathrm{b}}$ & $868.60 \pm 33.01^{\mathrm{a}}$ & $19.43 \pm 2.67^{\mathrm{a}}$ & $78.13 \pm 2.63^{a}$ \\
\hline Prednisolone & $6.95 \pm 0.77^{\mathrm{a}}$ & $9.87 \pm 0.28^{\mathrm{b}}$ & $16.76 \pm 0.50^{\mathrm{b}}$ & $51.68 \pm 1.62^{\mathrm{b}}$ & $855.50 \pm 34.00^{\mathrm{a}}$ & $17.95 \pm 2.21^{\mathrm{a}}$ & $77.15 \pm 1.05^{a}$ \\
\hline
\end{tabular}

Mean values within each column with different superscripts are significantly different, Duncan's test at $p \leq 0.05$. WBC $=$ white blood cells; RBC = red blood cells; $\mathrm{Hb}=$ hemoglobin; Hct = hematocrit; Plt = platelets; Neu = neutrophils; Lym = lymphocytes.

Table 8: Tumor necrosis factor- $a$ (TNF-a) levels in the treated colitis rats compared to those in the control

\begin{tabular}{cc}
\hline Groups & TNF-a levels $(\mathrm{ng} / \mathrm{mL})$ \\
\hline Non-colitis & $0.23 \pm 0.02^{\mathrm{a}}$ \\
PBS & $0.22 \pm 0.01^{\mathrm{a}}$ \\
HNKP & $0.23 \pm 0.01^{\mathrm{a}}$ \\
CMKP & \\
Colitis & $0.45 \pm 0.03^{\mathrm{c}}$ \\
PBS & $0.32 \pm 0.02^{\mathrm{b}}$ \\
HNKP & $0.33 \pm 0.02^{\mathrm{b}}$ \\
CMKP & $0.30 \pm 0.01^{\mathrm{b}}$ \\
Prednisolone &
\end{tabular}

Mean values within each column with different superscripts are significantly different, Duncan's test at $p \leq 0.05$.

at a dose of $150 \mathrm{mg} / \mathrm{kg}$ orally every day for 90 days. In addition, rice kefir also had no acute and sub-acute toxicities in the rat models. ${ }^{14,27}$

\section{CONCLUSION}

These findings indicate that rice kefir may offer protection against chemically induced tissue injury. To conclude, these rice milk kefirs have the potential to become functional foods with strong antioxidant and anti-inflammatory activities and they are safe for human consumption.

\section{ACKNOWLEDGEMENT}

This research was financially supported by Mahasarakham University, 2014. The authors would like to acknowledge the assistance from Miss Doungdean Promdema and Miss Emvipa Tongpan from the Natural Antioxidant Innovation Research Unit, Faculty of Technology, and also and Miss Supathida Junthakham and Miss Ratchadaporn Praneesap from Anima Laboratory, Department of Biology, Faculty of Science, Mahasarakham University, Thailand.

\section{CONFLICT OF INTEREST}

This research has no conflict of interest.

\section{REFERENCES}

1. Grewal RP, Yoshida T, Finch CE, Morgan TE. Scavenger receptor mRNAs in rat brain microglia are induced by kainic acid lesioning and by cytokines. Neuroreport. 1997;8(5):1077-81.

2. Tanguy S, Leiris J, Besse S, Boucher F. Ageing exacerbates the cardiotoxicity of hydrogen peroxide through the Fenton reaction in rats. Mech Ageing Dev. 2003;124(2):229-35. https://doi.org/10.1016/S0047-6374(02)00185-9.

3. Moongngarm A, Saetung N. Comparison of chemical compositions and bioactive compounds of germinated rough rice and brown rice. Food Chem. 2010;122(3):782-8. https://doi.org/10.1016/j.foodchem.2010.03.053.

4. Moongngarm A, Daomukda N, Khumpika S. Chemical compositions, phytochemicals, and antioxidant capacity of rice bran, rice bran layer, and rice germ. APCBEE Procedia. 2012;2:73-9. https://doi.org/10.1016/j.apcbee.2012.06.014.

5. Goufo P, Trindade H. Rice antioxidants: phenolic acids, flavonoids, anthocyanins, proanthocyanidins, tocopherols, tocotrienols, $\gamma$-oryzanol, and phytic acid. 2014; 2(2):75-104. http://doi.org/10.1002/fsn3.86.

6. Chunchom S, Talubmook C, Deeseenthum S. Antioxidant Activity, Biochemical Components and Sub-Chronic Toxicity of Different Brown Rice Kefir Powders. Pharmacogn J. 2017;9(3):388-94.

7. Deeseenthum S, Pejovic J. Bacterial inhibition and antioxidant activity of kefirproduced from Thai Jasmine rice milk. Biotechnol. 2010;9(3):332-7. https://doi. org/10.3923/biotech.2010.332.337.

8. Selamassakul O, Laohakunjit N, Kerdchoechuen O. Antioxidant activity of fermented brown rice by lactic acid bacteria. Agric Sci J. 2013;44(2):145-8.

9. Chen XQ, Nagao N, Itani T, Irifune K. Anti-oxidative analysis, and identification and quantification of anthocyanin pigments in different coloured rice. Food Chem. 2012;135(4):2783-8.

10. Mohanlal S, Parvathy R, Shalini V, Mohanan R, Helen A, Jayalekshmy A. Chemical indices, antioxidant activity and anti-inflammatory effect of extracts of the medicinal rice "njavara" and staple varieties: a comparative study. J. Food Biochem. 2012;37(3):369-80.

11. Kolakowski P, Ozimkiewicz M. Kefir grain tolerance to Escherichia coli: Contamination-industrial advantages. Dairy SciTechnol. 2012;92(6):709-18.

12. Kaizu H, Sasaki M, Nakajima H, Suzuki Y. Effect of antioxidative lactic acid bacteria on rats fed a diet deficient in vitamin E. J Dairy Sci. 1993;76(9):2493-9.

13. McCue PP, Shetty K. Phenolic antioxidant mobilization during yogurt Production from soymilk using kefir cultures. Process Biochem. 2005;40(5):1791-7.

14. Chunchom S, Deeseenthum $S$, Katisart $T$, Talubmook $C$. Acute toxicity of brown rice kefir powder. In Science and Technology (TICST), 2015 International Conference on. 2015;126-30. IEEE. https://doi.org/10.1109/ticst.2015.7369350.

15. Duarte WF, Dias DR, Oliveira JM, Teixeira JA, Silva JBA, Schwan RF. Characterization of different fruit wines made from cacao, cupuassu, gabiroba, jabuticaba and umbu. LWT-Food SciTechnology. 2010;43(10):1564-72. https://doi.org/10.1016/j. Iwt.2010.03.010.

16. Butkhup L, Samappito W, Samappito S. Phenolic composition and antioxidant activity of white mulberry (Morus alba L) fruits. Inter J Food Sci Technol. 2013; 48(5):934-40.

17. Chan EWC, Lim YY, Omar M. Antioxidant and antibacterial activity of leaves of Etlingera species (Zingiberaceae) in Peninsular Malaysia. Food Chem. 2007;104(4):1586-93. https://doi.org/10.1016/j.foodchem.2007.03.023.

18. Benzie IF, Strain JJ. The ferric reducing ability of plasma (FRAP) as a measure of "antioxidant power": the FRAP assay. Anal Biochem. 1996;239(1):70-6. https:// 
doi.org/10.1006/abio.1996.0292; PMid:8660627.

19. Rincón J, Fuertes J, Moya A, Monteagudo JM, Rodríguez L. Optimization of the fermentation of whey by Lactobacillus casei. Acta Biotechnol. 1993;13:323-31. https://doi: 10.1002/abio.370130403.

20. Mitchell CR, Mitchell PR, Nissenbaum R. Nutritional rice milk production. US Patent. 1988;4:744-992. https://www.google.com/patents/US4744992.

21. Soobrattee MA, Neergheen AS, Luximon-Ramma A, Aruoma OI, Bahorun OT. Phenolics as potential antioxidant therapeuticagents: mechanism and actions. Mutation Res Fundamental Mol. 2005;579(1):200-13.

22. Baba SA, Malik SA. Determination of total phenolic and flavonoid content, antimicrobial and antioxidant activity of a root extract of Arisaema jacquemontii Blume. J Taibah Uni Sci. 2015;9(4):449-54. https://doi.org/10.1016/j. jtusci.2014.11.001.

23. Halliwell B. Oxidative stress and cancer: have we moved forward. Biochem J. 2007;401(1):1-11.

24. Ramaiah SK. A toxicologist guide to the diagnostic interpretation of hepatic Biochemical parameters. Food ChemToxicol. 2007;45(9):1551-7. https://doi org/10.1016/j.fct.2007.06.007; PMid:17658209

25. Tilg H, Moschen AR. Adipocytokines: mediators linking adipose tissue, inflammation and immunity. Nature Reviews. 2006;6(10):772-83.

26. Geller DA, Billiar TR. Molecular biology of nitric oxide synthases. Cancer Metastasis Rev. 1998;17(1):7-23.

27. Chunchom S, Deeseenthum S, Talubmook C. Acute and sub-acute toxicity studies of Hawm Nil brown rice kefir powder. J SciTechnol MSU. 2016;35(6):678-88.

\section{GRAPHICAL ABSTRACT}

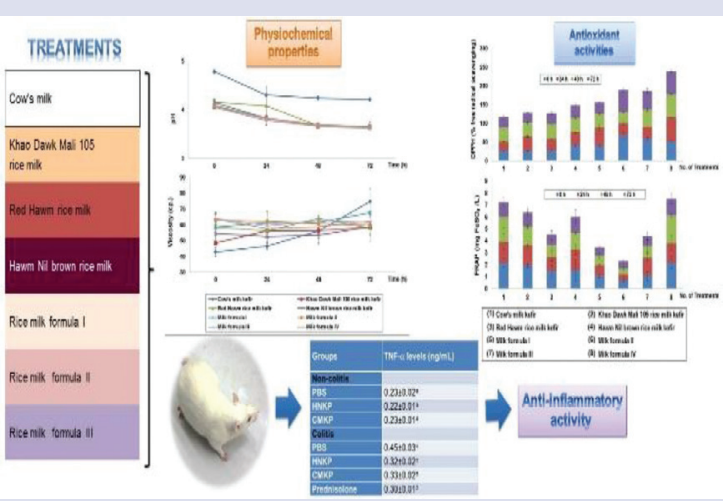

\section{SUMMARY}

- The characteristics, antioxidant property of Hawm Nil rice, Red Hawm rice, Khao Dawk Mali 105 rice milk kefirs and mixing of three color rice milk kefirs in different ratios were investigated.

- This research is the first report about anti-inflammatory activity of Hawm Nil rice kefir.

- Antioxidant activity from DPPH assay showed the most of rice milk kefirs had antioxidant activity higher than cow's milk.

- Blood chemistry, hematological values and tumor necrosis factor- $\alpha$ (TNF- $\alpha$ ) levels in colitis rats treated with Hawm Nil rice milk kefir did not differ from positive and negative control.

- TNF- $\alpha$ in the serum of colitis rats treated with Hawm Nil rice milk kefir significantly reduced when compared to negative control (PBS)

- The color rice kefirs may offer protection against on chemically induced tissue injury.

- Hawm Nil rice milk kefir exerted potential antioxidant and anti-inflammatory activities and was safe for human consumption.

\section{ABOUT AUTHORS}

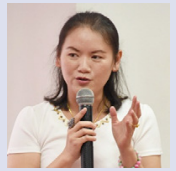

Dr. Sirirat Deeseenthum: Finished her Ph. D. degree in 2007 from Khon Kaen University, Thailand. At present, she is positioned as Assistant Professor in Biotechnology and also head of Natural Antioxidant Innovation Research Unit (NAIRU) at Faculty of Technology, Mahasarakham University, Maha Sarakham, Thailand. Dr. Sirirat is working on antioxidant activity of kefir produced from rice milk.

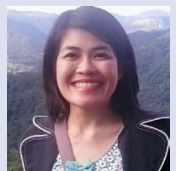

Dr. Vijitra Luang-In: Finished her Ph.D. degree in Microbiology \& Biochemistry, M.Res (Distinction) in Biochemical Research and also B.Sc. (Upper 2nd Class Hons) in Biotechnology from Imperial College, London. At present, she is an Assistant Professor in Department of Biotechnology, Faculty of Technology, Mahasarakham University, Thailand. Moreover, she also work in the Natural Antioxidant Innovation Research Unit (NAIRU) at Faculty of Technology, Mahasarakham University, Maha Sarakham, Thailand.

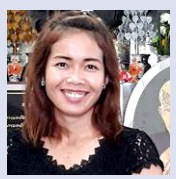

Dr. Supaporn Chunchom: Finished her Ph.D. degree in Biology at the Mahasarakham University (MSU), where she graduated in Bachelor and Master of Biology. Her doctoral research focused on the biochemical components, antioxidant and anti-inflammatory activities, and also toxicities of kefir powder from different brown rice milk kefir powders in vitro and in vivo tests. At present, she work in the Natural Antioxidant Innovation Research Unit (NAIRU) at Faculty of Technology, Mahasarakham University, Maha Sarakham, Thailand.

Cite this article: Deeseenthum S, Luang-In V, Characteristics of Thai Pigmented Rice Milk Kefirs with Potential as Antioxidant and Anti-Inflammatory Foods. Pharmacog J. 2018;10(1):154-61. 